\title{
New records of genus Tripos (Dinophyceae) around Jeju Island, Korea
}

\author{
Joon-Baek Lee ${ }^{1, *}$, So-Jeong An ${ }^{1}$, Han-Sik Chung ${ }^{1}$ and Md. Mahfuzur Rahman Shah ${ }^{2}$ \\ ${ }^{1}$ Department of Earth and Marine Sciences, College of Ocean Sciences, Jeju National University, Jeju 690-756, Korea \\ ${ }^{2}$ Jeju Sea Grant Center, Jeju National University, Jeju 690-756, Korea
}

\begin{abstract}
The morphology of 26 species of the genus Tripos was studied among a total of 51 species of this genus, which were taken using $20 \mu \mathrm{m}$ net samples from June 2006 to January 2011 at 14 stations around Jeju Island. Of these, 23 species were first described as new records in Korean waters and 3 species were redescribed. Short descriptions and synonyms are given for each species in the present study. The dinoflagellates of family Ceratiaceae include marine and freshwater species, belonged to originally the genus Ceratium. Recently, this genus were divided into a new combination with the genus Tripos, which contains the marine species, and the original genus Ceratium, including the freshwater species. We used the Tripos genus for the marine species in this study as a valid name.
\end{abstract}

Key words: Ceratiaceae, Ceratium, dinoflagellates, Jeju Island, new records, Neoceratium, Tripos

\section{INTRODUCTION}

As one genus of Dinophyceae, the genus Ceratium created by Schrank (1793) is one of the most important phytoplankton. The common size of Ceratium is large, which make them easy to collect. Morphological features of the Ceratium based on the tough theca are essential for taxonomic analysis. The genus includes a large number of species as plankton, and is widely distributed in all over the world ocean as well as rarely in freshwaters, such as lake and river. Over 120 marine species including varieties or forms have been described, but 62 among them are considered valid (Gómez 2005). Only four species with several varieties belong to freshwater species (Popovski and Pfiester 1990).

Many marine species belonged to the genus Ceratium have been moved to a new genus, Neoceratium, by Gómez et al. (2010), while freshwater species remains in the original genus Ceratium. The number of cingular plates and the considerable evolutionary distance of their re- spective small subunit ribosomal RNA gene (SSU rDNA) sequences are suggested as diagnosis to transfer to the Neoceratium genus for the marine species (Gómez et al. 2010, Tunin-Ley et al. 2012). However, Calado and Huisman (2010) remarked the priority for older synonyms of the Ceratium such as Tripos and other nomenclatural problems. Gómez (2010) insisted a confusion in using the Tripos, but recently Gómez (2013) reinstated the genus name of Tripos to replace the genus Neoceratium. To date, a total of 51 Ceratium species were identified around Jeju Island, which appeared in taxonomical monographs and ecological reports. Of these, 23 species were reported as new records in Korean waters. This study describes the newly recorded species with respect to classification and an easy taxonomical key based on light microscopy (LM) and scanning electron microscopy (SEM) criteria, and also provides the checklist of the genus Tripos based on the new combination. http://dx.doi.org/10.5141/ecoenv.2014.031

(c) This is an Open Access article distributed under the terms of the Creative Commons Attribution Non-Commercial Licens (http://creativecommons.org/licenses/by-nc/3.0/) which permits unrestricted non-commercial use, distribution, and reproduction in any medium, provided the original work is properly cited.
Received 10 October 2014, Accepted 29 October 2014

*Corresponding Author

E-mail: jblee@jejunu.ac.kr

Tel: +82-64-754-3435 


\section{MATERIALS AND METHODS}

Samplings were done from 14 stations located around Jeju Island during the period from June 2006 to May 2011 (Table 1). Plankton samples were obtained using a $20 \mu \mathrm{m}$ pore size plankton net and fixed with formaldehyde (final concentration of $0.4 \%$ ) or glutaraldehyde (final concentration of about 1\%). Planktonic dinoflagellates were identified using an Axioplan microscope (Carl Zeiss, Oberkochen, Germany). To make slide specimens for one species, the dinoflagellate samples were washed with distilled water, and then proceeded by the method described in Kim et al. (2013). For more detail observation, dinoflagellate cells were isolated with a micropipette, placed on a cover slip, air-dried, and coated with gold for observation with a Field Emission Scanning Electron microscope (JSM-6700F; JEOL, Tokyo, Japan). For identification, several monographs were used that were reported from different oceans, such as the Indian Ocean (Taylor 1976), the seas adjacent to Japan (Yamaji 1984: 97-158), the British and the Atlantic Ocean (Dodge 1982, 1985), the Kuroshio Current (Fujioka 1990) and Korean waters (Shim 1994: 349-419). For classification, the new combination with the genus Tripos was cited from Gómez (2013).

\section{RESULTS}

A total of 51 species of the genus Tripos were identified and classified from Jeju Island, as shown below. Among them, 23 species are described as a new record in Korean waters and 3 species are redescribed in this paper. An

Table 1. Sampling stations around Jeju Island, Korea, June 2006 - May 2011

\begin{tabular}{clrr}
\hline Stations & \multicolumn{1}{c}{ Location } & \multicolumn{2}{c}{ Geographic coordinates } \\
\hline J1 & Bukchon-ri coast & $33^{\circ} 34^{\prime} 30.8^{\prime \prime} \mathrm{N}$ & $126^{\circ} 41^{\prime} 02.6^{\prime \prime} \mathrm{E}$ \\
J2 & Samyang coast & $33^{\circ} 32^{\prime} 08.1^{\prime \prime} \mathrm{N}$ & $126^{\circ} 35^{\prime} 59.7^{\prime \prime} \mathrm{E}$ \\
J3 & Tap-dong coast & $33^{\circ} 32^{\prime} 18.7^{\prime \prime} \mathrm{N}$ & $126^{\circ} 33^{\prime} 02.9^{\prime \prime} \mathrm{E}$ \\
J4 & Iho coast & $33^{\circ} 30^{\prime} 18.7^{\prime \prime} \mathrm{N}$ & $126^{\circ} 27^{\prime} 05.1^{\prime \prime} \mathrm{E}$ \\
J5 & Aewol-ri coast & $33^{\circ} 29^{\prime} 37.7^{\prime \prime} \mathrm{N}$ & $126^{\circ} 20^{\prime} 31.1^{\prime \prime} \mathrm{E}$ \\
J6 & Hallim-ri coast & $33^{\circ} 26^{\prime} 34.2^{\prime \prime} \mathrm{N}$ & $126^{\circ} 14^{\prime} 01.3^{\prime \prime} \mathrm{E}$ \\
J7 & Chagwido coast & $33^{\circ} 19^{\prime} 02.7^{\prime \prime} \mathrm{N}$ & $126^{\circ} 08^{\prime} 02.4^{\prime \prime} \mathrm{E}$ \\
J8 & Gosan-ri coast & $33^{\circ} 15^{\prime} 31.8^{\prime \prime} \mathrm{N}$ & $126^{\circ} 09^{\prime} 52.6^{\prime \prime} \mathrm{E}$ \\
J9 & Hamo-ri coast & $33^{\circ} 11^{\prime} 44.7^{\prime \prime} \mathrm{N}$ & $126^{\circ} 13^{\prime} 57.5^{\prime \prime} \mathrm{E}$ \\
J10 & Hwasun-ri coast & $33^{\circ} 10^{\prime} 56.5^{\prime \prime} \mathrm{N}$ & $126^{\circ} 20^{\prime} 00.0^{\prime \prime} \mathrm{E}$ \\
J11 & Seogwipo coast & $33^{\circ} 13^{\prime} 31.4^{\prime \prime} \mathrm{N}$ & $126^{\circ} 34^{\prime} 17.1^{\prime \prime} \mathrm{E}$ \\
J12 & Namwon-ri coast & $33^{\circ} 14^{\prime} 53.0^{\prime \prime} \mathrm{N}$ & $126^{\circ} 43^{\prime} 10.6^{\prime \prime} \mathrm{E}$ \\
J13 & Pyoseon-ri coast & $33^{\circ} 17^{\prime} 01.3^{\prime \prime} \mathrm{N}$ & $126^{\circ} 49^{\prime} 27.8^{\prime \prime} \mathrm{E}$ \\
J14 & Seongsan-ri coast & $33^{\circ} 26^{\prime} 26.8^{\prime \prime} \mathrm{N}$ & $126^{\circ} 57^{\prime} 11.7^{\prime \prime} \mathrm{E}$ \\
\hline
\end{tabular}

asterisk $(*)$ mark indicates a newly recorded species and two asterisk $\left({ }^{* *}\right)$ mark indicates a redescribed species. The criteria for the identification of this genus include cell shape, apical and antapical horn shape, girdle displacement, thecal tabulation and ornamentation, apical and antapical spine or wing shape, etc. Photos were taken by LM and SEM focused on the criteria from the dorsal and ventral views.

\section{Checklist of the genus Tripos occurred around Jeju Island}

\author{
Class Dinophyceae G.S. West \& Fritsch 1927 \\ Order Gonyaulacales F.J.R. Taylor 1980 \\ Family Ceratiaceae Kofoid 1907 \\ Genus Tripos Bory 1823
}

Tripos arietinus (Cleve 1900) F. Gómez 2013

= Ceratium arietinum Cleve 1900

*Tripos axialis (Kofoid 1907) F. Gómez 2013

= Ceratium axiale Kofoid 1907

Tripos azoricus (Cleve 1900) F. Gómez 2013

= Ceratium azoricum Cleve 1900

Tripos brevis (Ostenfeld \& Johannes Schmidt 1901) F. Gómez 2013

= Ceratium breve (Ostenfeld \& Johannes Schmidt 1901)

Schröder 1906

Tripos candelabrus (Ehrenberg 1859) F. Gómez 2013

= Ceratium candelabrum (Ehrenberg 1859) F. Stein 1883

Tripos carriensis (Gourret 1883) F. Gómez 2013

= Ceratium carriense Gourret 1883

** Tripos contortus (Gourret 1883) F. Gómez 2013

= Ceratium contortum (Gourret 1883) Cleve 1900

Tripos deflexus (Kofoid 1907) F. Gómez 2013

= Ceratium deflexum (Kofoid 1907) Jørgensen 1911

Tripos extensus (Gourret 1883) F. Gómez 2013

= Ceratium extensum (Gourret 1883) Cleve 1900

Tripos furca (Ehrenberg 1834) F. Gómez 2013

= Ceratium furca (Ehrenberg 1834) Claparède \& J.

Lachmann 1859

Tripos fusus (Ehrenberg 1834) F. Gómez 2013

= Ceratium fusus (Ehrenberg 1834) Claparède \& J. Lachmann 1859

*Tripos fusus var. schuettii (Lemmermann 1899) F. Gómez 2013

= Ceratium fusus var. schuettii Lemmermann 1899

*Tripos geniculatus (Lemmermann 1899) F. Gómez 2013

= Ceratium geniculatum (Lemmermann 1899) Cleve 1900 
Tripos gibberus (Gourret 1883) F. Gómez 2013

= Ceratium gibberum Gourret 1883

*Tripos gibberus f. sinistrus (Gourret 1883) F. Gómez 2013

= Ceratium gibberum $\mathrm{f}$. sinistrum (Gourret 1883) Jørgensen 1911

Tripos gracilis (Pavillard 1905) F. Gómez 2013

= Ceratium gracile Pavillard 1905

*Tripos gracilis var. symmetricus (Pavillard 1905) F. Gómez 2013

= Ceratium gracile var. symmetricum (Pavillard 1905) Jørgensen 1911

Tripos horridus var. claviger (Kofoid 1907) F. Gómez 2013

= Ceratium horridum var. claviger (Kofoid 1907) H.W. Graham \& Bronik. 1944

*Tripos incisus (G. Karsten 1906) F. Gómez 2013

= Ceratium incisum (G. Karsten 1906) Jørgensen 1911

Tripos inflatus (Kofoid 1907) F. Gómez 2013

= Ceratium inflatum (Kofoid 1907) Jørgensen 1911

Tripos kofoidii (Jørgensen 1911) F. Gómez 2013

= Ceratium kofoidii Jørgensen 1911

*Tripos lamellicornis (Kofoid 1908) F. Gómez 2013

= Ceratium lamellicorne Kofoid 1908

*Tripos limulus (C.H.G. Pouchet 1883) F. Gómez 2013

= Ceratium limulus (C.H.G. Pouchet 1883) Gourret 1883

Tripos lineatus (Ehrenberg 1854) F. Gómez 2013

= Ceratium lineatum (Ehrenberg 1854) Cleve 1900

Tripos longirostrus (Gourret 1883) F. Gómez 2013

= Ceratium longirostrum Gourret 1883

*Tripos longissimus (Schröder 1900) F. Gómez 2013

= Ceratium longissimum (Schröder 1900) Kofoid 1907

Tripos lunula (Schimper 1900 ex G. Karsten 1906) F.

Gómez 2013

= Ceratium lunula Schimper 1900 ex G. Karsten 1906

Tripos macroceros (Ehrenberg 1840) F. Gómez 2013

= Ceratium macroceros (Ehrenberg 1840) Cleve 1899

**Tripos macroceros var. gallicus (Kofoid 1907) F. Gómez 2013

= Ceratium macroceros var. gallicum (Kofoid 1907) N. Peters 1934

Tripos massiliensis (Gourret 1883) F. Gómez 2013

= Ceratium massiliense (Gourret 1883) G. Karsten 1906

*Tripos massiliensis var. massiliensis (Gourret 1883) F. Gómez 2013

= Ceratium massiliense var. massiliense (Gourret 1883) Balech

*Tripos mollis (Kofoid 1907) F. Gómez 2013
= Certium molle Kofoid 1907

Tripos muelleri Bory 1825

= Ceratium tripos (O.F. Müller 1776) Nitzsch 1817

*Tripos muelleri var. atlanticus (Ostenfeld 1903) F.

Gómez 2013

= Ceratium tripos var. atlanticum (Ostenfeld 1903)

Paulsen 1908

*Tripos muelleri var. pulchellus (Schröder 1906) F. Gómez 2013

= Ceratium tripos var. pulchellum (Schröder 1906)

López 1955 ex Sournia 1973

*Tripos palmatus (Schröder 1900) F. Gómez 2013

= Ceratium palmatum (Schröder 1900) G. Karsten 1907

*Tripos paradoxides (Cleve 1900) F. Gómez 2013

= Ceratium paradoxides Cleve 1900

Tripos pentagonus (Gourret 1883) F. Gómez 2013

= Ceratium pentagonum Gourret 1883

*Tripos platycornis var. cuneatus (Jørgensen 1911) F. Gómez 2013

= Ceratium platycorne var. cuneatum Jørgensen 1911

*Tripos porrectus $\mathrm{f}$. megasomus (Jørgensen 1911) F. Gómez 2013

= Ceratium porrectum $\mathrm{f}$. megasomum Jørgensen 1911

Tripos praelongus (Lemmermann 1899) F. Gómez 2013

= Ceratium praelongum (Lemmermann 1899) Kofoid ex Jørgensen 1911

Tripos pulchellus (Schröder 1906) F. Gómez 2013

= Ceratium pulchellum Schröder 1906

*Tripos pulchellus f. semipulchellus (Jørgensen 1920) F. Gómez 2013

= Ceratium pulchellum $\mathrm{f}$. semipulchellum Jørgensen 1920

*Tripos ranipes var. palmatus (Schröder 1900) F. Gómez 2013

= Ceratium ranipes var. palmatum (Schröder 1900) Jørgensen 1920

*Tripos reflexus (Cleve 1900) F. Gómez 2013

= Ceratium reflexum Cleve 1900

**Tripos symmetricus (Pavillard 1905) F. Gómez 2013

= Ceratium symmetricum Pavillard 1905

*Tripos teres (Kofoid 1907) F. Gómez 2013

= Ceratium teres Kofoid 1907

Tripos trichoceros (Ehrenberg 1859) F. Gómez 2013

= Ceratium trichoceros (Ehrenberg 1859) Kent 1881

Tripos vultur (Cleve 1900) F. Gómez 2013

= Ceratium vultur Cleve 1900

*Tripos vultur f. angulatus (Jørgensen 1911) F. Gómez 2013

= Ceratium vultur f. angulatum (Jørgensen 1911) J. Schiller 1937 
*Tripos vulture f. robustus (Ostenfeld \& Johannes Schmidt 1901) F. Gómez 2013

= Ceratium vultur f. robustum (Ostenfeld \& Johannes Schmidt 1901) FJ.R. Taylor 1976

\section{Taxonomic description of unrecorded dinofla- gellates}

\section{Genus Tripos Bory 1823}

Tripos axialis (Kofoid 1907) F. Gómez 2013 (Fig. 1a)

Basionym: Ceratium axiale Kofoid 1907.

Synonym: Neoceratium axiale (Kofoid 1907) F. Gómez;

D. Moreira \& P. López-García 2010.

References: Kofoid 1907, p. 170, pl. 4, fig. 26; Fujioka 1990, p. 51, pl. 25, fig. 3.

Specimen examined: NIBRFL0000125563 at the National Institute of Biological Resources (NIBR), Incheon.

Description: The antapical horn is asymmetrically curved, like a bow. The apical horn is fine and long, with 1.5-2 times the length of the body. The part that links the epithecal body and the apical horn is smoothly curved.

Size: Length $220-240 \mu \mathrm{m}$, width 50-60 $\mu \mathrm{m}$.

Sampling: November 2009 in J7 (Chagwido coast, see Table 1 for the sign of sampling sites).

\section{Tripos contortus (Gourret 1883) F. Gómez 2013 (Fig. 1b)}

Basionym: Ceratium gibberum var. contortum Gourret 1883.

Synonym: Ceratium contortum (Gourret 1883) Cleve 1900; Neoceratium contortum (Gourret 1883) F. Gómez, D. Moreira \& P. López-García 2010.

References: Gourret 1883, T. 2, fig. 33; Yamaji 1984, p. 140, pl. 46, fig. 10; Shim 1994, p. 362, fig. 430; Okolodkov 2010, pl. 4, fig. 8, pl. 5, fig. 1, pl. 8, fig. 6, pl. 11, fig. 8, pl. 12, fig. 1.

Specimen examined: NIBRFL0000125588.

Description: The cell shape is long, with a quite long apical horn that is slightly curved. The antapical horns stretch in both directions, the right antapical horn is more curved in the middle part.

Size: Length 190-200 $\mu \mathrm{m}$, width 50-60 $\mu \mathrm{m}$.

Sampling: September 2010 in the southern sea of Jeju Island.

Tripos fusus var. schuettii (Lemmermann 1899) F. Gómez 2013 (Fig. 1c)

Basionym: Ceratium fusus var. schuettii Lemmermann 1899.

Synonym: Ceratium fusus var. schuettii Lemmermann 1899.
Reference: Yamaji 1984, p. 139, pl. 45, fig. 5.

Specimen examined: NIBRFL0000125589; Unrecorded species no. LJB2013-04 at the National Institute of Biological Resources (NIBR), Incheon.

Description: The body shape seems similar to that of the Ceratium fusus. The difference is that the epitheca is bulbous in shape and extends to a strong apical horn cone. The antapical horn has a single curved as long as the calyx. The apical horn is relatively short compared to the antapical horn.

Size: Length $250-350 \mu \mathrm{m}$, width $30-40 \mu \mathrm{m}$.

Sampling: July 2010 in J7 (Chagwido coast).

\section{Tripos geniculatus (Lemmermann 1899) F. Gómez 2013}

(Fig. 1d)

Basionym: Ceratium fusus var. geniculatum Lemmermann 1899.

Synonym: Ceratium geniculatum (Lemmermann 1899) Cleve 1900; Neoceratium geniculatum (Lemmermann 1899) F. Gómez, D. Moreira \& P. López-García 2010; Ceratium tricarinatum Kofoid.

References: Karsten 1907, pl. 50, fig. 3a, b; Subrahmanyan 1968, p. 28, figs. 43-45; Fujioka 1990, p. 55, pl. 27, figs, 2a, b; Okolodkov 2010, pl. 1, fig. 3, pl. 10, fig. 2.

Specimen examined: Unrecorded species no. LJB201308.

Description: The cells are spindle-shaped and relatively long. The cell body is long and clearly constricted in the middle. The epitheca is inflated, its distal part suddenly draws into an apical horn, and the hypotheca tapers into a long left antapical horn that is slightly curved. The apical horn is positioned closer to the left side of the cell, and is notably deflected to the left at its base. A reduced right antapical horn is present. The widest point is adjacent to the cingulum and also to the front of the constriction in the middle of the cell body.

Size: Length 150-160 $\mu \mathrm{m}$, width 10-20 $\mu \mathrm{m}$.

Sampling: July 2010 in J7 (Chagwido coast).

\section{Tripos gibberus f. sinistrus (Gourret 1883) F. Gómez 2013} (Fig. 1e)

Basionym: Ceratium gibberum var. sinistrum Gourret 1883.

Synonym: Ceratium gibberum f. sinistrum (Gourret 1883) Jørgensen 1911.

Reference: Yamaji 1984, p. 140, pl. 46, fig. 5.

Specimen examined: NIBRFL0000125591.

Description: The cell shape is slightly thick and flat. The apical horn is relatively stretched and the antapical horn is severely curved towards the dorsal side. 


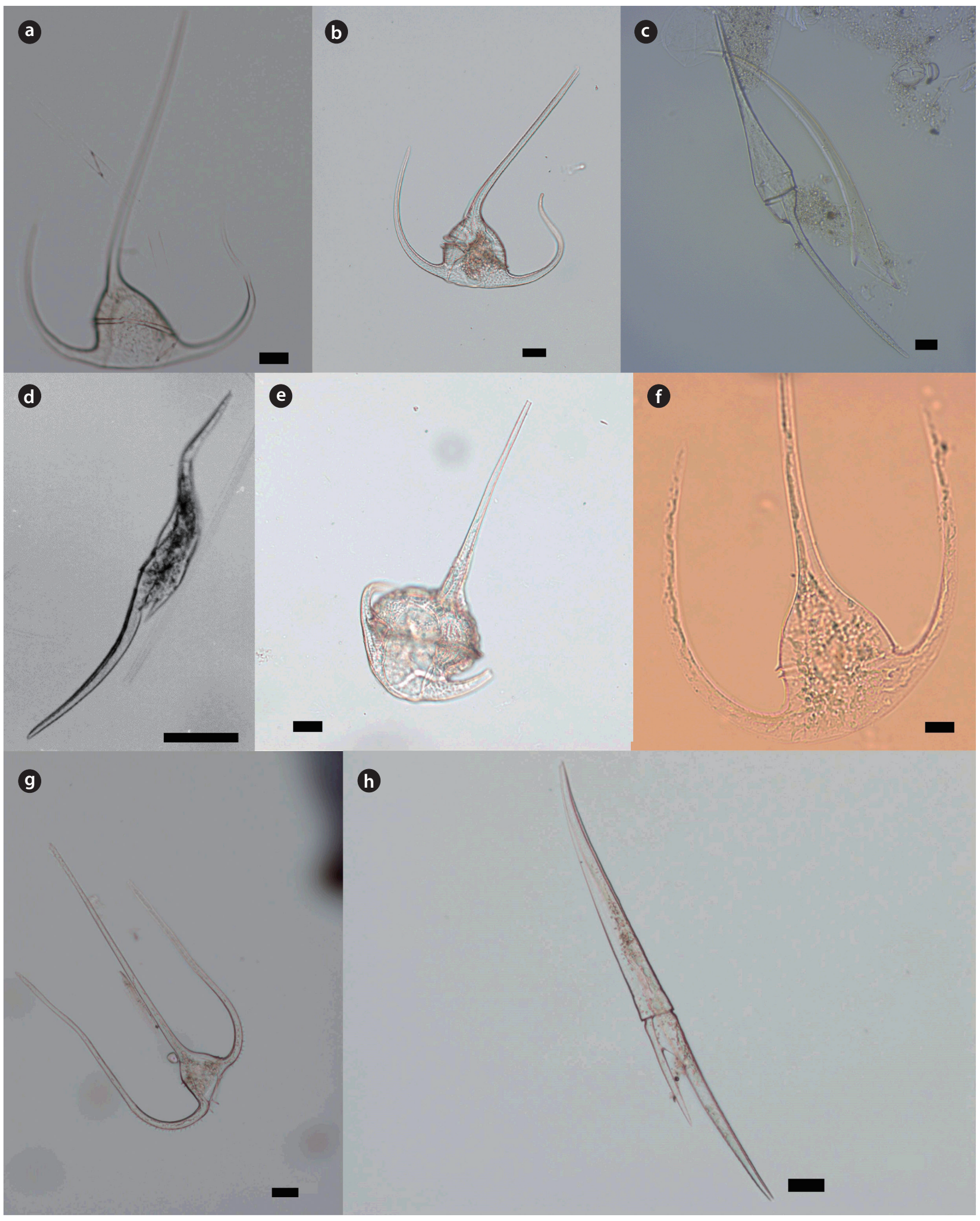

Fig. 1. Light micrographs of the genus Tripos. (a) T. axialis (DV), (b) T. contortus (DV), (c) T. fusus var. schuettii (DV), (d) T. geniculatus (DV), (e) T. gibberus var. sinistrus (VV), (f) T. gracilis var. symmetricus (DV), (g) T. mollis (DV), (h) T. incisus (VV). Scale bars, 20 m; DV, dorsal view; VV, ventral view. 
Size: Length 150-230 $\mu \mathrm{m}$, width 100-130 $\mu \mathrm{m}$.

Sampling: January 2011 in J14 (Seongsan-ri coast).

Tripos gracilis var. symmetricus (Pavillard 1905) F. Gómez 2013 (Fig. 1f)

Basionym: Ceratium symmetricum Pavillard 1905.

Synonym: Ceratium gracile var. symmetricum (Pavillard 1905) Jørgensen 1911.

Reference: Yamaji 1984, p. 145, pl. 47, fig. 13.

Specimen examined: NIBRFL0000125594.

Description: The cell is medium in size and slightly thin. The apical horn is slightly curved and upright, but both antapical horns have the same length and thickness. The girdle furrow is distinct and never converges.

Size: Length 100-130 $\mu \mathrm{m}$, width 50-70 $\mu \mathrm{m}$.

Sampling: January 2011 in J14 (Seongsan-ri coast).

Tripos incisus (G. Karsten 1906) F. Gómez 2013 (Fig. 1h)

Basionym: Ceratium furca var. incisum G. Karsten 1906.

Synonym: Ceratium incisum (G. Karsten 1906) Jørgensen 1911; Neoceratium incisum (G. Karsten 1906) F. Gómez, D. Moreira \& P. López-García 2010.

Reference: Karsten 1907, T. 23, fig. 6a, b; Fujioka 1990, p. 55, pl. 27, fig. 8.

Specimen examined: NIBRFL0000125565.

Description: The antapical horn stretches downward sharply. The left antapical horn is 2 times longer and 1.5 times thicker than right one. The apical horn is not distinguished.

Size: Length $260-280 \mu \mathrm{m}$, width $15-20 \mu \mathrm{m}$.

Sampling: January 2010 in J14 (Seongsan-ri coast).

Tripos lamellicornis (Kofoid 1908) F. Gómez 2013 (Fig. 2f)

Basionym: Ceratium lamellicorne Kofoid 1908.

Synonym: Ceratium lamellicorne Kofoid 1908.

Reference: Yamaji 1984, p. 146, pl. 48, fig. 8.

Specimen examined: Unrecorded species no. LJB200702.

Description: The antapical base is narrow and long, and stretched to the apical horn. The widest wing of the antapical horn is 2-2.5 times wider than the base part and is separate from the apical horn. The outside of the antapical horn has many gearwheel-like protuberances.

Size: Length 140-150 $\mu \mathrm{m}$, width $48-54 \mu \mathrm{m}$.

Sampling: November 2006 in 77 (Chagwido coast).

Tripos limulus (C.H.G. Pouchet 1883) F. Gómez 2013 (Fig. 2a)

Basionym: Ceratium tripos var. limulus C.H.G. Pouchet
1883.

Synonym: Ceratium limulus (C.H.G. Pouchet 1883) Gourret 1883; Neoceratium limulus (C.H.G. Pouchet 1883) F. Gómez, D. Moreira \& P. López-García 2010.

References: Gourret 1883, p. 33, T. 1, fig. 7; Fujioka 1990, p. 57, pl. 28, fig. 1; Okolodkov 2010, pl. 4, fig. 3, pl. 11, fig. 4. Specimen examined: NIBRFL0000125566.

Description: The apical horn length is relatively short, and there are protruding horns from both sides of the epitheca. The antapical horn is thick and stretches out and upward.

Size: Length 160-170 $\mu \mathrm{m}$, width $80-90 \mu \mathrm{m}$.

Sampling: January 2010 in J14 (Seongsan-ri coast).

Tripos longissimus (Schröder 1900) F. Gómez 2013 (Fig.

2b)

Basionym: Ceratium tripos f. longissimum Schröder 1900.

Synonym: Ceratium longissimum (Schröder 1900) Kofoid 1907; Neoceratium longissimum (Schröder 1900) F. Gómez, D. Moreira \& P. López-García 2010.

Reference: Schröder 1900, p. 16, T. 1, fig. 171; Wood 1963, p. 298, fig. 228.

Specimen examined: NIBRFL0000125564.

Description: Both sides of the antapical horn stretch upward with almost equal length, and the apical horn also has a straight, upright line. The bodies of the epitheca and the hypotheca are slightly small, but the whole body is bigger than the normal middle size of the genus Ceratium.

Size: Length $200-210 \mu \mathrm{m}$, width $30-40 \mu \mathrm{m}$.

Sampling: January 2010 in J7 (Chagwido coast).

Tripos macroceros var. gallicus (Kofoid 1907) F. Gómez 2013 (Fig. 2c)

Basionym: Ceratium gallicum Kofoid 1907.

Synonym: Ceratium macroceros var. gallicum (Kofoid 1907) N. Peters 1934.

Reference: Dodge 1982, p. 235, fig. 31a; Yamaji 1984, p. 146, pl. 48, fig. 13; Shim 1994, p. 374, fig. 448; Okolodkov 2010, pl. 6, fig. 4, pl. 8, fig. 4, pl. 13, fig. 3.

Specimen examined: Unrecorded species no. LJB201004.

Description: The apical horn is slightly obliquely stretched, and the antapical horn is separated in a fan shape. The back side of the antapical horn has many spines, and the girdle furrow has a clear, oblique line.

Size: Length 250-350 $\mu \mathrm{m}$.

Sampling: November 2010 in J8 (Gosan-ri coast). 


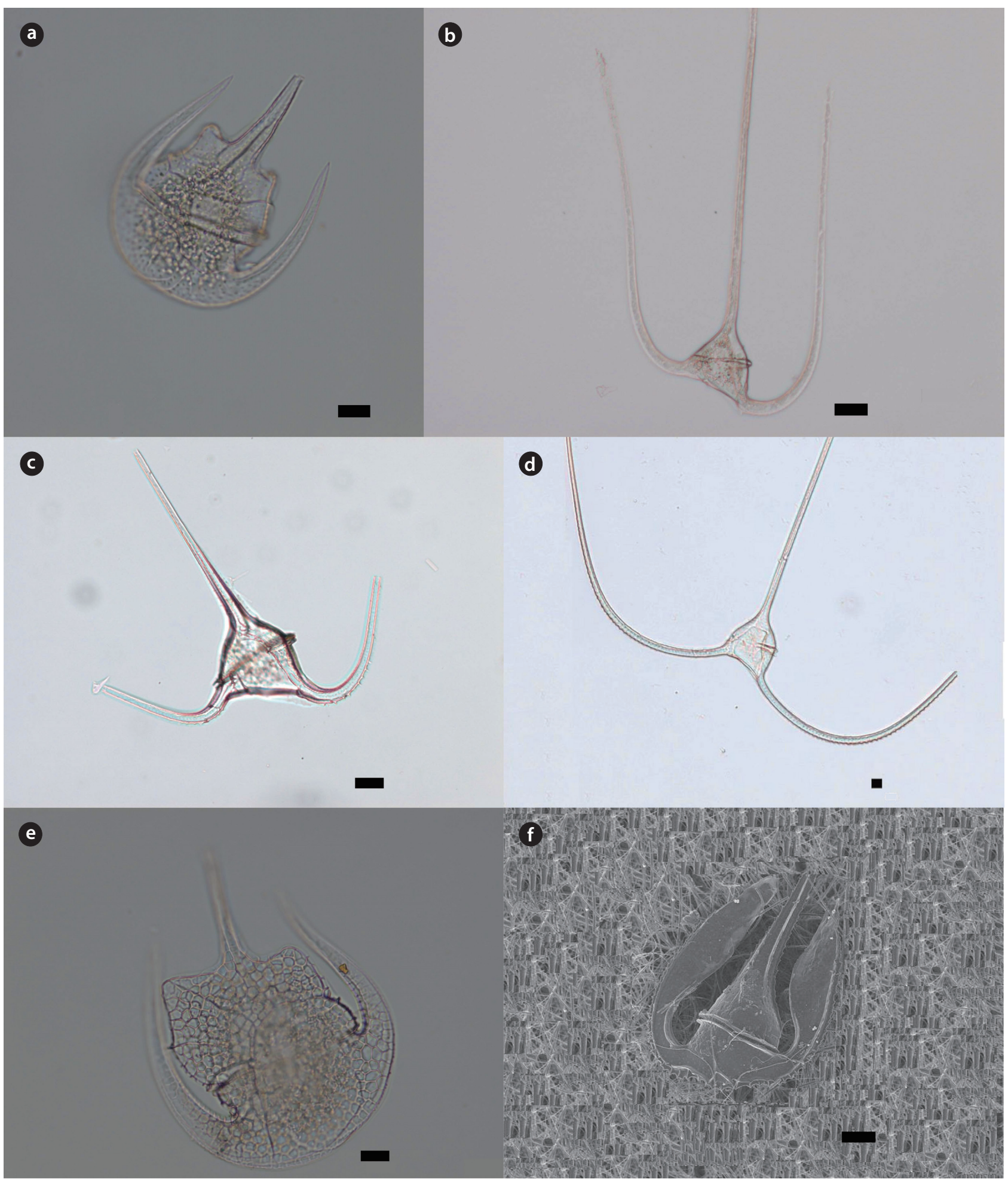

Fig. 2. Light micrographs and scanning electron micrograph (SEM) of the genus Tripos. (a) T. limulus (VV), (b) T. longissimus (DV), (c) T. macroceros var. gallicus (DV), (d) T. massiliensis var. massiliensis (DV), (e) T. paradoxides (VV), (f) T. lamellicornis (SEM, DV). Scale bars, 20 um; DV, dorsal view; VV, ventral view. 
Tripos massiliensis var. massiliensis (Gourret 1883) F. Gómez 2013 (Fig. 2d)

Basionym: Ceratium tripos var. massiliense Gourett 1883.

Synonym: Ceratium massiliense var. massiliense (Gourret 1883) Balech.

Reference: Gourret 1883, p. 27, T. 1, fig. 2; Fujioka 1990, p. 57, pl. 28, fig. 7; Licea et al. 1995, pl. 19, fig. 6.

Specimen examined: Unrecorded species no. LJB200803.

Description: The antapical horn is very long, curved like a bow. The apical horn is slightly shorter than the antapical horn. The main body is relatively small, compared to the three long horns, but it looks well balanced in shape to float.

Size: Length 400-500 $\mu$ m, width $80-90 \mu \mathrm{m}$.

Sampling: September 2008 in J14 (Seongsan-ri coast).

\section{Tripos mollis (Kofoid 1907) F. Gómez 2013 (Fig. 1g)}

Basionym: Certium molle Kofoid 1907.

Synonym: Certium molle Kofoid 1907; Ceratium intermedium (Jörgensen) Jörgensen; Ceratium claviger Kofoid.

Reference: Yamaji 1984, p. 152, pl. 50, fig. 10.

Specimen examined: NIBRFL0000125567.

Description: The antapical horn is fine, long, and stretches upward. Numerous spine are visible around the base of the hypotheca. The apical horn is as long as the antapical one and has a similar length, but the cell body is relatively small.

Size: Length $210-220 \mu \mathrm{m}$, width $30-40 \mu \mathrm{m}$.

Sampling: November 2009 in J7 (Chagwido coast).

\section{Tripos muelleri var. atlanticus (Ostenfeld 1903) F. Gómez} 2013 (Fig. 4c)

Basionym: Ceratium tripos f. atlanticum Ostenfeld 1903.

Synonym: Ceratium tripos var. atlanticum (Ostenfeld 1903) Paulsen 1908; Neoceratium tripos var. atlanticum (Ostenfeld 1903) A.F. Krachmalny 2011.

Reference: Jørgensen 1911, pl. 10; Yamaji 1984, p. 145, pl. 47, fig. 4-; Fujioka 1990, p. 61, pl. 30, fig. 2.

Specimen examined: NIBRFL0000125604; Unrecorded species no. LJB2013-07.

Description: The body shape is similar to that of the Ceratium tripos, but it is concave at the bottom of the body. The furrow of the girdle has a characteristic curvature. The left horn is slightly smaller than the right horn.

Size: Length 90-120 $\mu \mathrm{m}$, width 45-60 $\mu \mathrm{m}$.

Sampling: July 2010 in J7 (Chagwido coast).
Tripos muelleri var. pulchellus (Schröder 1906) F. Gómez 2013 (Fig. 4d)

Basionym: Ceratium pulchellum Schröder 1906.

Synonym: Ceratium tripos var. pulchellum (Schröder 1906) López 1955 ex Sournia 1973.

Reference: Schröder 1906, p. 358, fig. 27; Fujioka 1990, p. 61 , pl. 30, fig. 3 .

Specimen examined: Unrecorded species no. LJB200804.

Description: The whole body shape is similar to the Ceratium tripos. The hypothecal body is swollen, and the right antapical horn is curved towards the inner side.

Size: Length 190-200 $\mu \mathrm{m}$, width 80-90 $\mu \mathrm{m}$.

Sampling: October 2008 in J9 (Hamo-ri coast).

Tripos palmatus (Schröder 1900) F. Gómez 2013 (Fig. 3d)

Basionym: Ceratium tripos var. macroceros Schröder 1900.

Synonym: Ceratium palmatum (Schröder 1900) G. Karsten 1907.

Reference: Cleve 1900, p. 15, T. 7, fig. 1; Yamaji 1984, p. 146, pl. 48, fig. 10.

Specimen examined: NIBRFL0000125599.

Description: The apical horn is bent as it stretches upward, and the end of the antapical horn is split in the shape of fingers. Numerous spines are located around the outside of the antapical horn and the base of the hypothecal body.

Size: Length 130-150 $\mu \mathrm{m}$, width 30-40 $\mu \mathrm{m}$.

Sampling: January 2011 in J14 (Seongsan-ri coast).

Tripos paradoxides (Cleve 1900) F. Gómez 2013 (Fig. 2e)

Basionym: Ceratium paradoxides Cleve 1900.

Synonym: Neoceratium paradoxides (Cleve 1900) F. Gómez, D. Moreira \& P. López-García 2010.

Reference: Cleve 1900, p. 15, T. 7, fig. 14; Yamaji 1984, p. 146, pl. 50, fig. 5; Fujioka 1990, p. 57, pl. 28, fig. 8.

Specimen examined: NIBRFL0000125568.

Description: The apical horn is short and slightly thick. The upper side of the epitheca displays swelling in the shape of a half quadrangle around the right and left side of the apical horn. The antapical horn is very thick, but becomes thinner towards the end of the horn. A net shape of mesh is visible on a wide surface area of the epithecal upper body.

Size: Length $230-250 \mu \mathrm{m}$, width 110-120 $\mu \mathrm{m}$.

Sampling: January 2010 in J14 (Seongsan-ri coast). 
Tripos platycornis var. cuneatus (Jørgensen 1911) F. Gómez 2013 (Fig. 3a)

Basionym: Ceratium platycorne var. cuneatum Jørgensen 1911.

Synonym: Ceratium platycorne var. cuneatum Jørgensen 1911.

Reference: Jørgensen 1911, p. 59, fig. 126.

Specimen examined: Unrecorded species no. LJB200703.

Description: The hypothecal base is relatively narrow, and both antapical horns have flat and wide wings that stretch upward. The widest part of the wing is 2 times the length of the base part of the antapical horn. The wing is separate from the epithecal body and the apical horn. The end of the antapical horn is truncated, like a knife face.

Size: Length 350-400 $\mu \mathrm{m}$, width 80-90 $\mu \mathrm{m}$.

Sampling: February 2007 in J7 (Chagwido coast).

\section{Tripos porrectus f. megasomus (Jørgensen 1911) F. Gó- mez 2013 (Fig. 3b)}

Basionym: Ceratium porrectum f. megasomum Jørgensen 1911.

Synonym: Ceratium porrectum f. megasomum Jørgensen 1911; Ceratium ponectum $\mathrm{f}$. megasoma Jørgensen.

Reference: Jørgensen 1911, p. 34, fig. 64; Schiller 1937, pp. 590; Subrahmanyan 1968, p. 129; Yamaji 1984, p. 159, pl. 51, fig. 4; Fujioka 1990, p. 59, pl. 29, fig. 2.

Specimen examined: NIBRFL0000125603 (Ceratium ponectum f. megasoma Jørgensen); Unrecorded species no. LJB2013-05 (Ceratium porrectum $\mathrm{f}$. megasoma).

Description: This is a robust species. The left contour of the epitheca become strongly convex and is abruptly drawn out into a robust, short anterior horn, which is strikingly broadened at the base and covered with toothed ridges in old, large individuals. The distal portion is narrowed. The antapical horns are uniformly arched and are generally rather short; they are approximately as long as or at times longer than the cell body, diverging at the apex, and parallel to rarely somewhat converging; the right horn is usually somewhat slender and shorter. The armor is robust, with lists, pores, and winged lists.

Size: Length 130-150 $\mu \mathrm{m}$, width 50-70 $\mu \mathrm{m}$.

Sampling: May 2010, January 2011 in J14 (Seongsan-ri coast).

Tripos pulchellus f. semipulchellus (Jørgensen 1920) F. Gómez 2013 (Fig. 3c)

Basionym: Ceratium pulchellum f. semipulchellum Jørgensen 1920.

Synonym: Ceratium pulchellum f. semipulchellum Jør- gensen 1920.

Reference: Schröder 1906, p. 358, fig. 27.

Specimen examined: NIBRFL0000125606; Unrecorded species no. LJB2013-06.

Description: The body is always longer than it is broad. The posterior contour is clearly convex, particularly on the right side. The apical horn is strikingly long and robust, uniformly broad up to the apex, and rarely broader in the middle than at the end. The hypotheca is slightly concave, almost straight, and slightly inclined to the left side contour. The posterior contour of the cell is convex, usually uniformly merging with the left antapical horn, whereas the right is clearly delimited (slightly so with a very small right horn). The antapical horns are rather short and less robust than the apical horn; the left one is particularly beautifully and uniformly arched, with the ends directed almost parallel to the apical horn, or the left sometimes somewhat divergent. The right horn is clearly more weakly developed than the left. The winged lists are absent.

Size: Length 120-150 $\mu \mathrm{m}$, width 45-55 $\mu \mathrm{m}$.

Sampling: July 2010 in J13 (Pyosun-ri coast).

\section{Tripos ranipes var. palmatus (Schröder 1900) F. Gómez 2013 (Fig. 3e)}

Basionym: Ceratium tripos var. macroceros f. palmatum Schröder 1900.

Synonym: Ceratium ranipes var. palmatum (Schröder 1900) Jørgensen 1920.

Reference: Cleve 1900, p. 15, T. 7, fig. 1; Fujioka 1990, p. 59, pl. 29, fig. 4 .

Specimen examined: Unrecorded species no. LJB200705.

Description: The end of the antapical horns looks like a fen shape and is characterized with fine projects. The projects have 6 radial axes stretching outside of them.

Size: Length 300-350 $\mu \mathrm{m}$, width 60-80 $\mu \mathrm{m}$.

Sampling: February 2007 in J7 (Chagwido coast).

\section{Tripos reflexus (Cleve 1900) F. Gómez 2013 (Fig. 3f)}

Basionym: Ceratium reflexum Cleve 1900.

Synonym: Neoceratium reflexum (Cleve 1900) F. Gómez, D. Moreira \& P. López-García 2010.

Reference: Cleve 1900, p. 15, T. 7, figs. 8, 9; Yamaji 1984, p. 159, pl. 51, fig. 5-; Fujioka 1990, p. 59, pl. 29, fig. 6.

Specimen examined: Unrecorded species no. LJB201309.

Description: The species is of a medium size and has very characteristic features. The body is slightly compressed. The epitheca is broad and low. The hypotheca is 

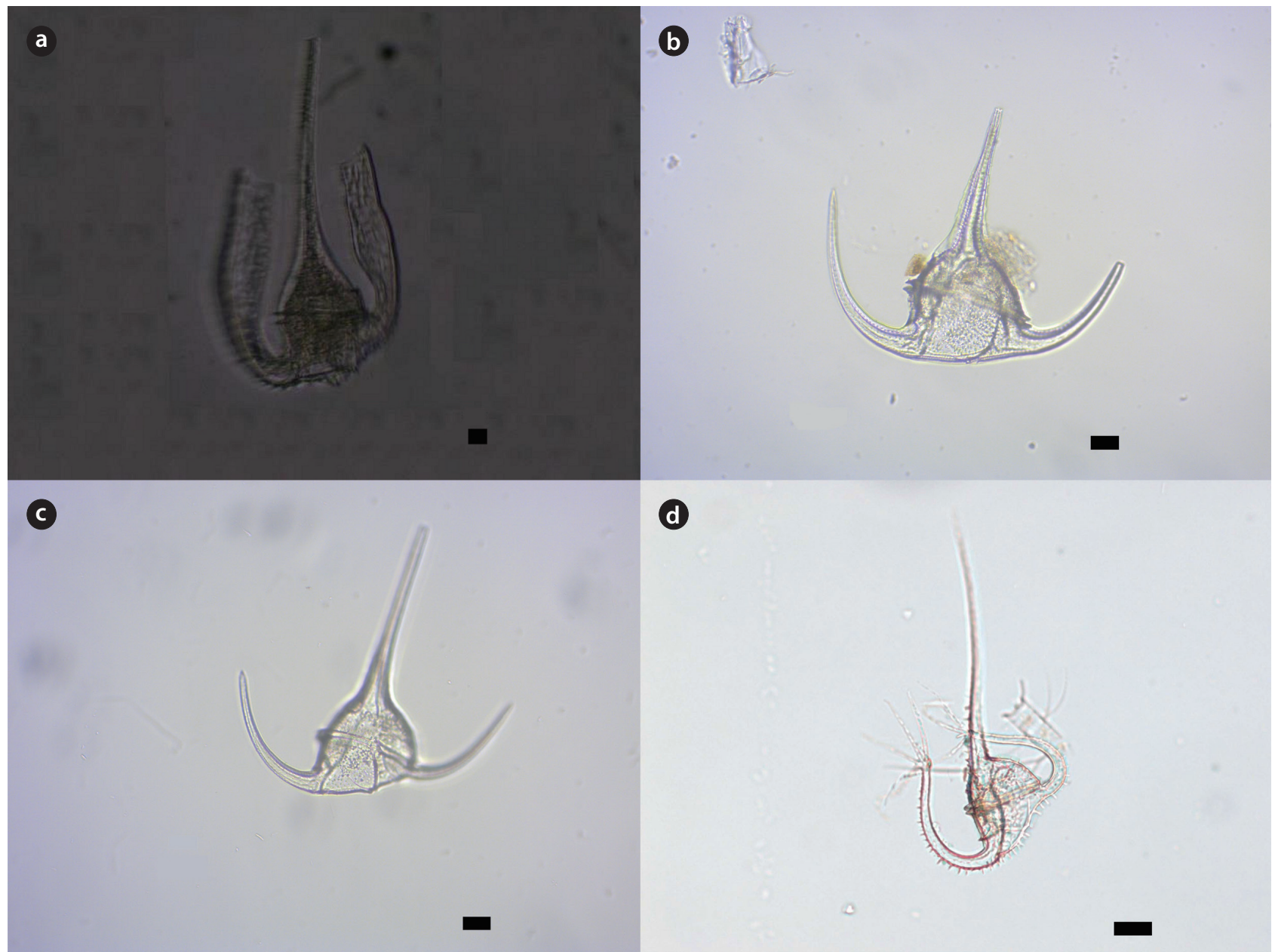

d

e

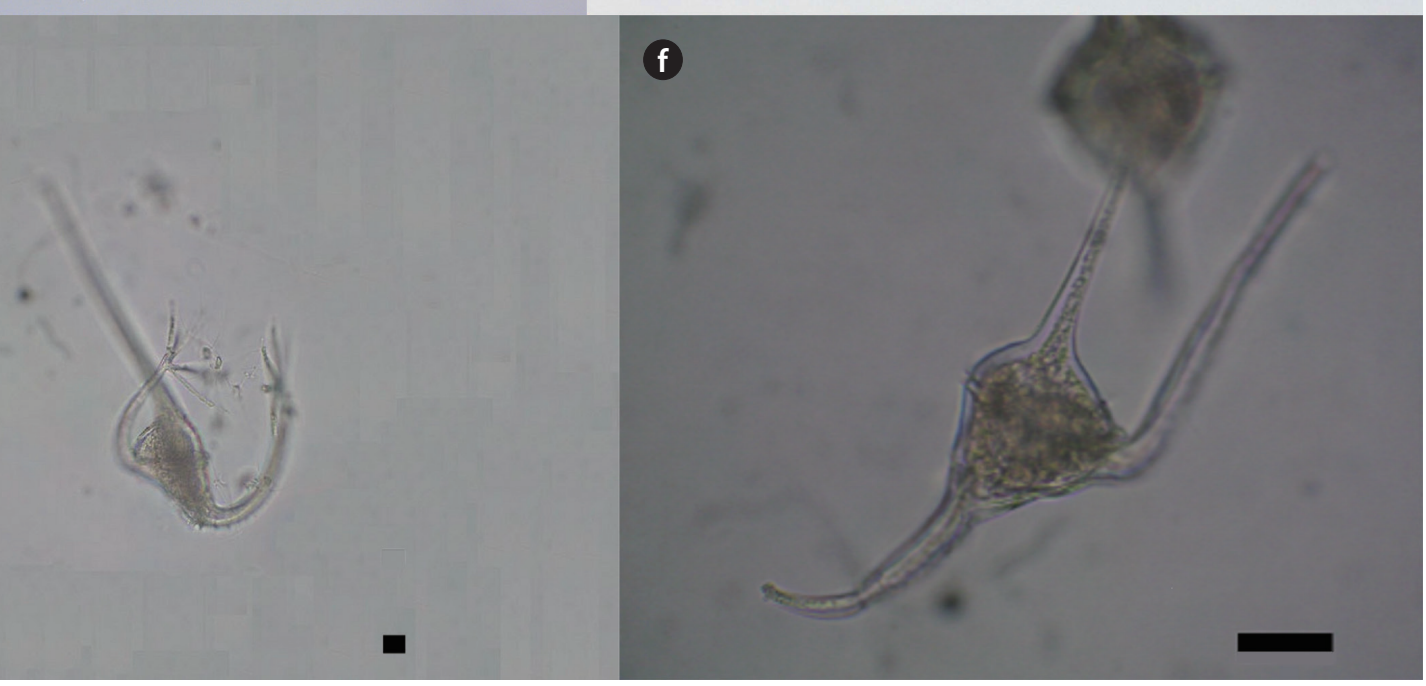

Fig. 3. Light micrographs of the genus Tripos. (a) T. platycornis var. cuneatus (DV), (b) T. porrectus f. megasomus (DV), (c) T. pulchellum f. semipulchellum (DV), (d) T. palmatus (DV), (e) T. ranipes var. palmatus (VV), (f) T. reflexus (DV). Scale bars, $20 \mu \mathrm{m}$; DV, dorsal view; VV, ventral view. 


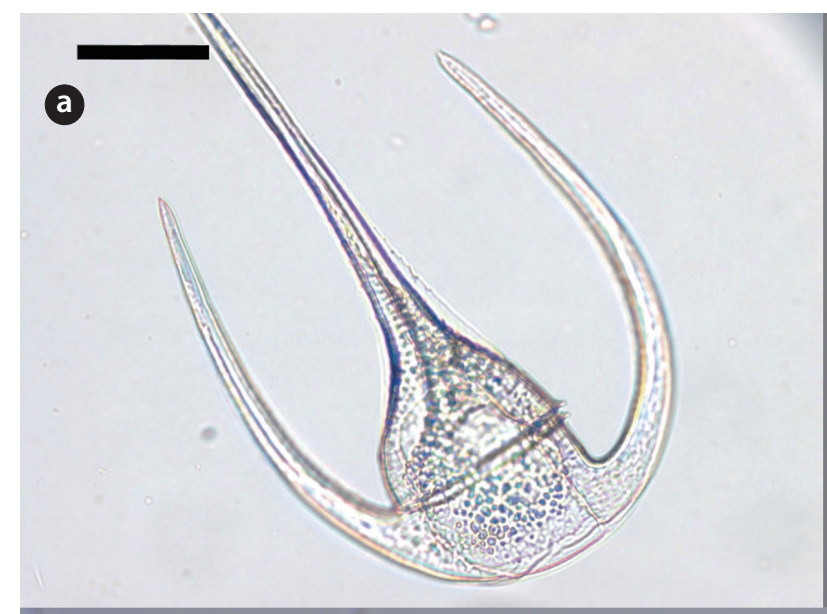

b

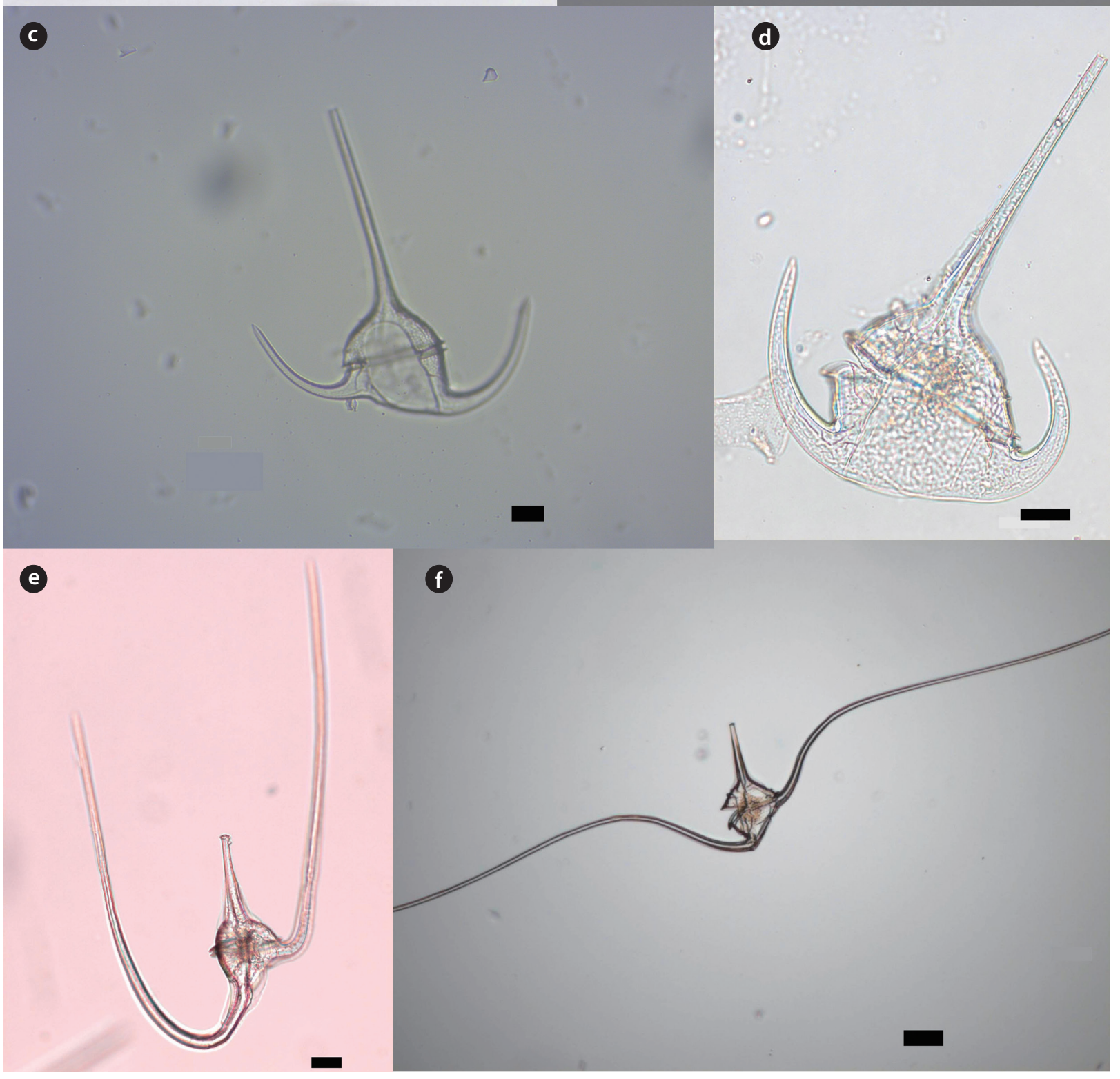

Fig. 4. Light micrographs of the genus Tripos. (a) T. symmetricus (VV), (b) T. teres (DV), (c) T. muelleri var. atlanticus (VV), (d) T. muelleri var. pulchellus (DV), (e) T. vultur f. robustus (DV), (f) T. vulturf. angulatum (DV). Scale bars, 20 m; DV, dorsal view; VV, ventral view. 
almost double the length of the epitheca. All three horns, particularly the apical one, have a widened base and a thick wall towards the apex, are narrow and thin walled at the proximal part, and are beset with more or less clear and somewhat dentate winged lists. The lists are well developed on the transverse furrow. The left horn at the base is at first oblique and points backward, then bends back and is somewhat twisted. The right horn is approximately the same length or usually somewhat longer. The base is perpendicular to the body, then suddenly bends forward and is almost straight; it diverges less than $20-25^{\circ}$ relative to the apical horn. The armor usually clears with small but robust, twisted lists and striking pores. In the orientation of the posterior, the horn of this species is unique.

Size: Length 200-250 $\mu \mathrm{m}$.

Sampling: October 2010 in J7 (Chagwido coast).

Tripos symmetricus (Pavillard 1905) F. Gómez 2013 (Fig. 4a) Basionym: Ceratium symmetricum Pavillard 1905.

Synonym: Neoceratium symmetricum (Pavillard 1905)

F. Gómez, D. Moreira \& P. López-García 2010; Ceratium gracile (Gourret) Jørgensen.

References: Pavillard 1905, p. 52, T. 1, fig. 4; Shim 1994, p. 378, fig. 454; Okolodkov 2010, pl. 5, fig. 9, pl. 12, fig. 9.

Specimen examined: Unrecorded species no. LJB201310.

Description: The cell body has convex sides, sometimes slightly inflated on the left side, with a notably convex posterior margin that lacks a notch between the antapical horns, which are slightly longer than they are wide. The apical horn is rather short, slightly curved, and positioned centrally. The antapical horns are relatively long, continuously curved, directed anteriorly, and positioned at about equal distance from the cell body. The widest point is adjacent to the cingulum and the antapical horns.

Size: Length 100-130 $\mu \mathrm{m}$, width 50-70 $\mu \mathrm{m}$.

Sampling: July 2010 in J7 (Chagwido coast).

\section{Tripos teres (Kofoid 1907) F. Gómez 2013 (Fig. 4b)}

Basionym: Ceratium teres Kofoid 1907.

Synonym: Neoceratium teres (Kofoid 1907) F. Gómez, D. Moreira \& P. López-García 2010.

Reference: Kofoid 1907, p. 308, T. 29, figs. 34-36; Yamaji 1984, p. 134, pl. 44, fig. 17; Okolodkov 2010, pl. 3, fig. 4, pl. 10., fig. 12.

Specimen examined: NIBRFL0000125569.

Description: The apical horn is very thin, long, and upwardly straight. The main body is relatively big compared to the horn. The antapical horn is very short and blunt. The right antapical horn is 2 times longer than the left one.
Size: Length $90-100 \mu \mathrm{m}$, width $15-20 \mu \mathrm{m}$.

Sampling: January 2010 in J7 (Chagwido coast).

\section{Tripos vultur f. angulatus (Jørgensen 1911) F. Gómez}

\section{3 (Fig. 4f)}

Basionym: Ceratium sumatranum f. angulatum Jørgensen 1911.

Synonym: Ceratium vultur f. angulatum (Jørgensen 1911) J. Schiller 1937.

Reference: Cleve 1900, p. 15, T. 7, fig. 5.

Specimen examined: Unrecorded species no. LJB201402.

Description: The whole shape is similar to the Ceratium vultur, but the distance between both antapical horns is very wide (about 1,800 $\mu \mathrm{m}$ ). The epithecal and the hypothecal body are rigid.

Size: Length $60-70 \mu \mathrm{m}$ (apical horn only), width $20-40$ $\mu \mathrm{m}$.

Sampling: September 2008 in the northeastern sea of Jeju Island.

\section{Tripos vultur f. robustus (Ostenfeld \& Johannes Schmidt} 1901) F. Gómez 2013 (Fig. 4e)

Basionym: Ceratium robustum Ostenfeld \& Johannes Schmidt 1901.

Synonym: Ceratium vultur f. robustum (Ostenfeld \& Johannes Schmidt 1901) FJ.R. Taylor 1976.

Reference: Cleve 1990, p. 15, T. 7, fig. 5; Fujioka 1990, p. 61, pl. 30, fig. 6 .

Specimen examined: Unrecorded species no. LJB201403.

Description: The epitheca is relatively small, and the apical horn is short. Both antapical horns are long, and the right antapical horn is longer. The wings in the antapical horn and the hypotheca are characterized.

Size: Length 300-400 $\mu \mathrm{m}$, width 50-90 $\mu \mathrm{m}$.

Sampling: July 2010 in J8 (Gosan-ri coast).

\section{DISCUSSION}

Gómez et al. (2010) insisted the separation of the genus Ceratium into two distinct genera, a new genus name Neoceratium for the marine species and the Ceratium for the freshwater species, on the basis of both the number of cingular plates and the considerable evolutionary distance of their respective SSU rDNA sequences, which form two well-defined monophyletic clades. However, Calado and Huisman (2010) commented a priority of the new genus name Neoceratium as they proposed a valid 
genus name Tripos. Recently, Gómez (2013) moved all species of the genus Neoceratium to the genus Tripos with a checklist. Regarding the name of species in the both genera, the Ceratium is neuter, but the Tripos is masculine. Therefore, most of the adjectival epithets should be changed accordingly. Thus, the use of the Tripos genus name and the new combinations will induce numerous misspellings of the epithets and considerable confusion. The present study follows the new combination of the genus Tripos Bory 1823 and the treatment of basionym and homotypic synonym proposed by Gómez (2013). Cercaria tripos O.F. Müller 1776 is the basionym of the genus Tripos, where many varieties and forma are included, and the name of type species is also changed to Tripos muelleri according to nomenclature priority (Gómez 2013).

A total of 36 Ceratium species in Korean waters were described by Shim (1994). Shim et al. (1981) described 10 Ceratium species in Yeosu Bay, and Han and Yoo (1983) described 5 Ceratium species in Jinhae Bay. In addition Kim et al. (2013) reported 4 Ceratium species as first record in Korean waters. The present study suggests that all marine Ceratium species should move to the genus Tripos proposed by Gómez (2013). Over the last several years, we have found a total of 51 Tripos species that were identified around Jeju Island. Of these, 23 species were recorded for the first time in the adjacent sea of Jeju Island, as well as in Korean waters.

\section{ACKNOWLEDGMENTS}

This work was supported by a grant from the National Institute of Biological Resource (NIBR), funded by the Ministry of the Environment (MOE) of the Republic of Korea (NIBR201401204), and also supported by Jeju Sea Grant Center, funded by the Ministry of Ocean and Fisheries (MOF) of the Republic of Korea.

\section{LITERATURE CITED}

Calado AJ, Huisman JH. 2010. Commentary: F. Gómez, D. Moreira and P. López-García (2010). Neoceratium gen. nov., a new genus for all marine species currently assigned to Ceratium (Dinophyceae). Protist 161: 517-519.

Cleve PT. 1900. Plankton from the southern Atlantic and southern Indian Ocean. Öfver K Vet-Akad Förhand 8: 919-938.

Dodge JD. 1982. Marine Dinoflagellates of the British Isles. Her Majesty's Stationery Office, London.
Dodge JD. 1985. Atlas of Dinoflagellates. Farrand Press, London.

Fujioka S. 1990. Illustrations of the Plankton of the Kuroshio Waters: Plankton in Amami-Oshima Island Coastal Waters. Nagasaki Publication Culture Association, Nagasaki. (in Japanese)

Gómez F. 2005. A list of dinoflagellates in the world's oceans. Acta Bot Croat. 64: 129-212.

Gómez F. 2010. A genus name for the marine species of Ceratium: reply to commentary by A. Calado and J.M. Huisman on Gómez, F., D.Moreira and P. López-García (2010). Neoceratium gen. nov., a new genus for all marine species currently assigned to Ceratium (Dinophyceae). Protist 161: 520-522.

Gómez F. 2013. Reinstatement of the dinoflagellate genus Tripos to replace Neoceratium, marine species of Ceratium (Dinophyceae, Alveolata). CICIMAR Oceanides 28: $1-22$.

Gómez F, Moreira D, López-Garcia P. 2010. Neoceratium gen. nov., a new genus for all marine species currently assigned to Ceratium (Dinophyceae). Protist 161: 35-54.

Gourret P. 1883. Sur les Peridiniens du Golfe de Marseille. Ann Mus Hist Nat Marseille Zool 1: 1-114.

Han MS, Yoo KI. 1983. A taxonomical study on the dinoflagellates in Jinhae bay, I: armored and unarmored dinoflagellates. Bull KORDI 5: 37-47. (in Korean)

Jørgensen E. 1911. Die Ceratien: eine kurze monographie der gattung Ceratium Schrank. Int Rev ges Hydrobiol Hydrogr 4: 1-124.

Karsten G. 1907. Das Indische Phytoplankton nach dem Material der Deutschen Tiefsee-Expedition 1898-1899. Wiss Ergebn Tiefsee-Exped 2: 221-548.

Kim HS, Kim SH, Jung MM, Lee JB. 2013. New record of dinoflagellates around Jeju Island. J Ecol Environ 36: 273291.

Kofoid CA. 1907. Dinoflagellata of the San Diego region, III. Descriptions of new species. Univ Calif Publ Zool 3: 299340.

Kofoid CA. 1908. Exuviation, autotomy and regeneration in Ceratium. Univ Calif Publ Zool 4: 345-386.

Licea S, Moreno JL, Santoyo H, Figueroa G. 1995. Dinoflageladas del Golfo de California. Universidad Antonoma de Baja California Sur, La Paz.

Okolodkov YB. 2010. Ceratium Schrank (Dinophyceae) of the National Park Sistema Arrecifal Veracruzano), Gulf of Mexico, with a key for identification. Act Bot Mex 93: 41-101.

Pavillard J. 1905. Recherches sur la flore pélagique (Phytoplankton) de l'Etang de Thau. Thèse. Montane et Sicardi, Paris. 
Popovski J, Pfiester LA. 1990. Dinophyceae (Dinoflagellida). In: Süsswasserflora von Mitteleuropa (Ettl H, Gerloff J, Heynig H, Mollenhauer H eds). Fischer Verlag, Stuttgart, pp 88-218.

Schiller J. 1937. Dinoflagellatae (Peridineae) in monographischer Behandlung; Teil 2. Akademische Verlagsgesellschaft MBH, Leipzig.

Schröder B. 1900. Das Phytoplankton des Golfes von Neapel. Mitteil Zool Stat Neapel 14: 1-38.

Schröder B. 1906. Beiträge zur Kenntnis des Phytoplanktons warmer Meere. Vierteljahrsschr Naturf Ges Zürich 51: 319-377.

Schrank FP. 1793. Mikroskopische Wahrnehmungen. Der Naturforscher (Halle) 27: 26-37.

Shim JH. 1994. Illustrated Encyclopedia of Fauna and Flora of Korea, Vol. 34. Marine Phytoplankton. Ministry of Education, Seoul. (in Korean)

Shim JH, Shin EY, Choi JK. 1981. A taxonomical study on the dinoflagellates of the coastal waters in the vicinity of Yeosu, Korea. J Oceanol Soc Korea 16: 57-98. (in Korean) Subrahmanyan R. 1968. The Dinophyceae of the Indian Seas. Part I. Genus Ceratium. Marine Biology Association of India, Mandapam Camp.

Taylor FJR. 1976. Dinoflagellates from the international Indian Ocean expedition. Bibliotheca Bot 132: 1-234.

Tunin-Ley A, Vaugelas JD, Garcia D, Marro S, Lemée R. 2012. A new collaborative web site to improve the accuracy of dinoflagellate identification: focus on the morphologically-variable genus Neoceratium (Schrank) Gomez, Moreira et Lopez-Garcia. Cryptogam Algol 33: 399-404.

Wood EJF. 1963. Dinoflagellates in the Australian region. II. Recent collections. Tech Pap Div Fish Oceanogr CSIRO 14: 4-51.

Yamaji I. 1984. Illustrations of the Marine Plankton of Japan. 3rd ed. Hoikusha Publishing Co Ltd, Osaka. (in Japanese) 